\title{
On Communicative Translation of Chinese Political Discourse
}

\author{
Jun Chen \\ College of Humanities and Law \\ Fujian Agriculture and Forestry University \\ Fuzhou, Fujian, China \\ cjgullit@163.com
}

\begin{abstract}
The paper explores the communicative translation principles of Chinese political discourse, which serves as one of the important platforms for China's global communication. It argues that the traditional source-text-oriented view of translation may hinder the audience's sound understanding of the complex and ideological connotations, therefore major concerns should also be given to the readers' understanding and acceptability in the process of translating Chinese political discourse which features ideology-influenced translation practice, culture-loaded abbreviations and metaphors. The paper also proposes three communicative translation principles, namely, downplaying of ideological influence, paraphrase of abbreviated terms and coordinated literal translation and explanation for mapping metaphors, to fulfill the purpose of cross-cultural communication and projecting a favorable image of China to the world.
\end{abstract}

Keywords-communicative translation principles; Chinese political discourse; ideological influence; metaphor

\section{INTRODUCTION}

As globalization being the current trend, China has been increasingly integrated into the international community. With interaction between China and other countries in the world increases, a qualified and decent translation of Chinese official discourse is of great importance and urgency for it serves as a window for foreigners to know more about China as well as a bridge for China to communicate her voice with the outside world and construct her positive image abroad.

There is a long-established principle that political translation should be source-text-oriented in China [1], [2], [3]. However, "the traditional view concerning political translation impairs a profound understanding of the intricacy and ideological implications involved in the practice of translating Chinese political discourse" [4]. Consequently, this paper, with the communicative function of political translation in mind, probes into to the communicative translation strategies of Chinese political discourse.

\section{COMMUNICATIVE TRANSLATION REVISITED}

Peter Newark, an influential English translation theorist influenced by Buhler's functional theory, classifies the texts into three types: the expressive text, the informative text and the vocative text by taking into consideration the specific role

This paper is sponsored by 2016 Fujian Education and Research Project $A$ Study of Translator's Ethics in Publicity Translation (JAS160166) and FLTRP College English Research Project Translation Ethics in Universities' Overseas Publicity (20150016). each plays in translation. He points out that "few texts are purely expressive, informative or vocative, most texts include all three functions, with an emphasis on one of the three" [5]. Based on the text typology, he puts forth the theory of "communicative translation" and explains it as "communicative translation attempts to produce on its readers an effect as close as possible to that obtained on the readers of the original" [6]. In other words, communicative translation tends to be smoother, easier and clearer for its focus is to convey message or information in an acceptable form in the target language so that the target readers will not meet many difficulties or obscurities and the translated text would be familiar to them in their own culture.

\section{RHETORICAL FEATURES OF CHINESE POLITICAL DISCOURSE}

The data of this study consist of Report on the Work of the Government delivered on March 5, 2017 and Xi Jinping: The Governance of China. The former is the latest political document while the latter, comprising 79 speeches, talks, interviews, instructions and correspondence of Xi Jinping from November 15, 2012 to June 13, 2014, contributes to interpreting China's path of development, domestic and foreign policies, and response to international concerns about China. Based on text typology (see Figure 1 [7]), Chinese political discourse lies between the expressive text and the vocative text since it is both official statement and publicity text. Some unique rhetorical features of Chinese political discourse are observed after a close reading of the texts.

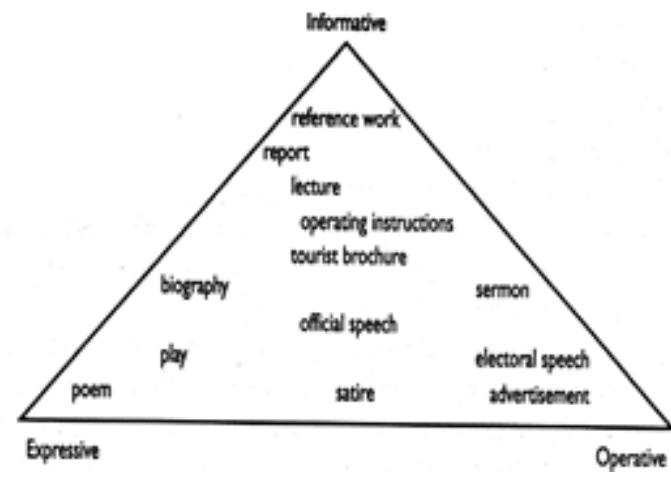

Fig. 1. Text types and text varieties 


\section{A. Ideology-influenced Translation Practice}

There is always a context in which translation takes place, a history from which a text emerges and into which a text is transposed. Therefore, as a social activity, translation inevitably carries traces of ideological manipulation, which is especially true to Chinese political translation.

The translation of Chinese political writings and speeches, which often requires multi-institutional cooperation, is performed by Central Compilation \& Translation Bureau and The Department of Translation and Interpretation in Ministry of Foreign Affairs of the People's Republic of China. Most of the professional translators in these two organizations are members of the CPC who are followers of the prevailing ideologies pursuing a politically correct translation ethics. In other words, they are required "to integrate their individual knowledge into the institutionalized models and transform the ideological message into textual representation" [4]. It can be observed that ideology not only influences the selection of texts for translation, but also plays as "an invisible hand" [8] to control the production, publication and popularity of the translated texts.

\section{B. Adoption of Abbreviated Terms for Conciseness}

One of the customary practices of Chinese political documents is to use abbreviated terms when it comes to introduce the burgeoning concepts in society. The abbreviated terms, usually presented in the numerical form of two characters, three characters or four characters, gains wider public acceptance thanks to their down-to-earth style, compendious but comprehensive connotation, innovative and conspicuous formation, catchy and rhythmic pronunciation. Furthermore, through the application of these authoritative coinages that are presented in a familiar manner to Chinese people, the intended symbolic power can be achieved by producing persuasion and identification among the audience.

\section{Application of Metaphors to Simplify Complexity}

Metaphors exist in our everyday life since "our ordinary conceptual system, in terms of which we both think and act, is fundamentally metaphorical in nature" [9]. The metaphors employed in modern Chinese political discourse are varied, ranging from journey metaphor, building metaphor, war metaphor to family metaphor, with the first three categories enjoy the highest frequency. In the Report on the Work of the Government delivered at the Fifth Session of the 12th National People's Congress of the People's Republic of China on March 5, 2017, we can detect journey metaphor ( “要继续以壮士断 腕的勇气，坚决披荆斩棘向前推进”; We need to continue to pursue with the courage to make painful self-adjustments and overcome all odds), war metaphor ( “坚决打好蓝天保卫 战”; We will make our skies blue again) and building metaphor ( “织密扎牢民生保障网”; We will weave a strong safety net to ensure people's wellbeing). The application of these metaphors "do more than simplify complexity for the analyst or decision maker. They clothe the intangible, giving life to abstractions." [10]

\section{COMMUNICATIVE TRANSLATION PRINCIPLES OF CHINESE POLITICAL DISCOURSE}

Political discourse, mainly concerned with political affairs and current affairs, aims to convey information and influence the audience. Like every other texts, political translation has its own functions, which can be summarized as: (a) Publicize policies formulated by the state and the Communist Party of China (CPC); (b) Reflecting the political stance of China in the important political matters and international affairs; (c) Call for the nationwide enthusiasm of the Chinese people toward building the socialism with Chinese characteristics; (d) Promote communication between China and other countries in the world.

The traditional view concerning political translation is source-text-oriented, which however, will sometimes only yield awkward or even unacceptable translation for target audience because of its rigid adherence to literal faithfulness. This paper explores the two-fold goals for today's translation of political discourse for global communication. On one hand, ensuring accuracy in political documents translation is the primary principle; while on the other hand, the translator should also give major concerns to produce natural and decent translation through effective use of symbolic resources for the sake of facilitating communication with target communities as well as projecting a favorable image of China to the world.

\section{A. Downplaying of Ideological Influence}

As a cross-cultural social practice, translation can never happen in a vacuum environment, but rather influenced by certain linguistic, ideological and poetic factors. To the ruling class, ideology, which reflects in real life as political control over the society, is the safeguard of their power as well as the management of the nation. As a social and human practice, translation can never escape being determined by ideology. On the other hand, translations that have been approved by authorities also contribute to consolidate the society's ideology.

However, translators should not just impose the ideology in the source text on target readers, otherwise the intended communicative function of the target text may not be successfully achieved. In other words, translators should reproduce the spirit of the source text based on a sound textual analysis of the source text. When necessary, translators should downplay some of the ideologically influenced expressions on the basis of political correctness to transfer information.

Example 1: 在战争浩劫中空前觉醒的各国人民，强烈 要求掌握自己的命运。

People of all countries who had achieved unprecedented awakening through the baptism of war demanded control of their destiny.

Example 2: 提高海洋资源开发能力, 发展海洋经济, 保护海洋生态环境, 坚决维护国家海洋权益, 建设海洋强 国。

We should enhance our capacity for exploiting marine resources, develop the marine economy, protect the marine ecological environment, resolutely safeguard China's maritime rights and interests, and build China into a maritime power. 
In Example 1, the equivalent expression for “战争浩劫” is "war calamity", which bears evident trace of ideological influence. The translator diminishes the ideological flavor and resorts to the expression of "baptism of war" which may easily produce identification among target audience due to its religious implications. It also conveys the message that war will arouse people to fight for freedom in a subtle way close to the cognition of target communities.

In Example 2, the translation "a maritime power" may result in the misunderstanding that China will acquire the ability or official capacity to exercise control over other countries which goes against China's foreign policy of "opposing hegemonism and upholding the five principles of peaceful coexistence". Therefore, it is more desirable to downplay it as "improve maritime capabilities" to achieve the communicative function.

\section{B. Paraphrase of Culture-loaded Abbreviations}

As indicated earlier, Chinese political documents employ abbreviations frequently to make the writings economical with eye-catching effects. However, translators cannot presuppose that the target audiences are equipped with enough prior knowledge regarding China's culture, social development and its newly-emerged concepts. In other words, literal translation of these concise but comprehensive abbreviated terms will probably not help the audience to have a better understanding of China. It is advisable for translators to adopt the strategy of paraphrase which is especially effective to make explicit the implied meanings of those culture-loaded terms and expressions.

Example 3: 深入贯彻习近平总书记系列重要讲话精神 和治国理政新理念新思想新战略, 统筹推进 “五位一体” 总体布局。

Put into practice the principles from General Secretary Xi Jinping's major addresses and his new vision, thinking, and strategies for China's governance and promote balanced economic, political, cultural, social, and ecological progress. 策。

Example 4: 统一城乡义务教育学生 “两免一补” 政

We will combine the separate policies for rural and urban students receiving compulsory education that waive tuition and miscellaneous fees, supply free textbooks, and grant living allowances for boarders from financially disadvantaged families.

In both Example 3 and Example 4, the translator paraphrases the connotations of the two italic Chinese expressions ( “五位一体” , “两免一补”) to “reproduce the matter without the manner, or the content without the form of the original" [5]. More often than not, the paraphrase translation reads more smooth and acceptable to the target readers since it rewrites from the readers' point of view and respects their intelligence. At the same time, paraphrase of the source text offers much more information to audience, and thus ensures the credibility of the content and helps to bridge the cognition gap.

\section{Coordinated Literal Translation and Explanation for Mapping Metaphors}

As Newmark put it, "the translation of any metaphor is the epitome of all translation, in that it always offers choices in the direction either of sense or of an image, or a modification of one, or a combination of both." [5] Some metaphors are universal, indicating that people of different cultures can understand the similar vehicle of the metaphor when it is transplanted from one culture to another. In this case, literal translation will fulfill the intended purpose of communication. On the other hand, conceptual shift takes place when some metaphors are introduced to a different language due to cultural differences, which calls for necessary explanations on the translator's part.

Example 5: 我们坚信, 有党的坚强领导, 坚持党的基 本路线, 坚定不移走中国特色社会主义道路, ……我国 发展一定能够创造新的辉煌。

We should follow the leadership of the Party, uphold the Party's fundamental political guidelines, and keep to the path of socialism with Chinese characteristics; It is our firm belief that by doing this, we will make great new achievements in China' s development.

Example 6: 保持惩治腐败的高压态势，做到有案必 查、有腐必惩, 坚持“老虎” “苍蝇”一起打。

We must be tough in cracking down on corruption, and ensure that all cases of corruption are investigated and that all corrupt officials are punished, catching "tigers" as well as "flies" - senior officials as well as junior ones guilty of corruption.

In Example 5, the English word "path" can be used as a journey metaphor to refer to "a set of actions, especially ones which lead to a goal or result", which shares the identical meaning of the Chinese expression “走中国特色社会主义道 路”. With similar mapping condition satisfied, the translator uses literal translation to transplant the metaphor in target domain.

In Example 6, the source text utilizes the contrast of size between tigers and flies to give a vivid illustration of the different positions and powers of corrupted officials. However, literal translation alone will not be able to reproduce the symbolic meanings in the English culture. To remove the linguistic obstructs set by different mapping condition, the translator adds necessary explanations to retain the source cultural flavor and guides the audience to focus on the rhetorical effect of the source domain [11]

\section{CONCLUSION}

Translation of political discourse is one of the important vehicles for China to communicate her voice to the outside world. The traditional view centering on faithfulness to the source text, however, may hinder an adequate understanding of the complex implications involved in translation of Chinese political discourse. 
This paper argues that for today's translation of political discourse for global communication, accuracy to the source text is still one of the primary principles that translators should follow; while on the other hand, major concerns should also be given to yield idiomatic translation for the sake of facilitating communication with target communities. It identifies the prominent rhetorical features of Chinese political documents, namely, ideology-influenced translation practice, adoption of abbreviated terms and frequent application of metaphors. At the same time, three corresponding communicative translation strategies are explored, including downplaying of ideological influence, paraphrase of culture-loaded abbreviations and coordinated literal translation and explanation for mapping metaphors.

It has to be pointed out that there are still many other aspects involved in Chinese political translation waiting to be explored. For instance, quantitative analysis can be incorporated into the study to survey the responses and acceptance of audience. Further efforts are worthwhile in this regard.

\section{REFERENCES}

[1] Z. Cheng, Papers on Translation Studies. Beijing: Foreign Language Teaching and Research Press, 2002. (In Chinese).
[2] Z. Cheng, On translation of political documents, Chinese Translators Journal, vol. 25, p. 50, January 2004. (In Chinese).

[3] J. Guo, On the political implications of diplomatic terms, Chinese Translators Journal, vol. 23, pp. 59-60, November 2002. (In Chinese).

[4] J. Li and S. Li, New trends of Chinese political translation in the age of globalization, Perspectives: Studies in Translatology, Vol.23, pp. 424439, February 2015.

[5] P. Newmark, A Textbook of Translation. Hertfordshire: Prentice Hall Ubterbatuibak Ltd., 1988, pp. 42, 113, 46.

[6] P. Newmark, Approaches to Translation. Oxford: Pergamon Press Ltd., 1981, p. 39.

[7] J. Munday, Introducing Translation Studies: Theories and Applications. NJ: Routledge, 2007, p. 74.

[8] D. Wang, An invisible hand: ideological manipulation in the practice of translation, Chinese Translators Journal, vol. 24, pp. 16-23, September 2003. (In Chinese).

[9] G. Lakoff, M. Johnson, Metaphors We Live By. Chicago: University of Chicago Press, 1980, p.1.

[10] S. Thompson, Politics without Metaphors is Like a Fish without Water, in Metaphor: implications and applications, J. S. Mio, A. N. Katz Eds. Mahwah, NJ: Lawrence Erlbaum Associates, Publishers, 1996, pp.185201.

[11] R. Lin, D. Lin: Chinese-English translation of political documents: translation from a cultural perspective - exemplified by English language version of Xi Jinping: The Governance of China, Southeast Academic Research, vol. 6, pp. 235-240, November 2016. (In Chinese). 